\title{
OLHARES
}

\section{Educação Literária e autoria negra feminina brasileira: um olhar para o conto "Quantos Filhos Natalina Teve?", de Conceição Evaristo}

\author{
Vanderleia da Silva Oliveira \\ Universidade Estadual do Norte do Paraná \\ vanderleiaoliveira@uenp.edu.br \\ Lucas Breda Magalhães \\ Universidade Estadual do Norte do Paraná \\ lucasbredam@gmail.com
} RESUMO

Este trabalho tem como objetivo a análise do conto "Quantos filhos Natalina teve?", de Olhos D'água (2016), de Conceição Evaristo, tendo em vista que ele expressa a representação de indivíduos historicamente marginalizados, inserindo-se numa importante linha de força da literatura brasileira contemporânea, sob a perspectiva da educação literária e da autoria negra feminina contemporânea. Evidencia-se que este texto literário oportuniza a reflexão sobre o lugar de pertencimento de vozes subalternizadas na sociedade ao passo que a produção literária dessas vozes é relevante devido a sua potencialidade na formação do sujeito leitor em espaço escolar. Para tanto, os problemas levantados foram analisados a partir de pressupostos teóricos ligados à Educação Literária, ao Letramento Literário, ao contexto de produção e aos estudos sobre linhas de força da produção literária contemporânea, com foco na Literatura Afro-brasileira e Negro-brasileira. Como resultado, verifica-se que o conto de Evaristo figura um importante texto para a sala de aula e um passo rumo ao ensino de literatura mais representativo.

Palavras-chave: Educação literária; Representação da mulher negra; Conceição Evaristo.

\section{Literary education and Brazilian black-woman writing: a look to the short story "Quantos filhos Natalina teve?", by Conceição Evaristo}

\section{ABSTRACT}

This paper aims to present the analysis of the short story entitled "Quantos filhos Natalina teve?", published in Olhos D'água (2016), by Conceição Evaristo. This text 
provides a perspective of historically marginalized individuals that represent a power line in contemporary Brazilian literature, besides the fact a literacy education gives opportunity of the reflection of social place and potentiality that this production has to the reader's formation at school. The problems discussed were analyzed based on the theoretical assumptions related to Literary Education, Literary Literacy, the context of production and studies on the power lines of contemporary literary production, with a focus on Afro-Brazilian Literature and Black-Brazilian Literature. As a result, Evaristo's short story is an important text for the classroom and a step towards the teaching of more representative literature.

Keywords: Literacy education; The representation of black woman; Conceição Evaristo.

\section{Para começar a prosa...}

Natalina, finalmente, encontra-se feliz, após confrontar os múltiplos obstáculos da própria existência como mulher negra e pobre. Ela está grávida de seu "primeiro" filho:

\footnotetext{
Natalina alisou carinhosamente a barriga, o filho pulou lá de dentro respondendo ao carinho. Ela sorriu feliz. Era a sua quarta gravidez, e seu primeiro filho. Só seu. De homem algum, de pessoa alguma. Aquele filho ela queria, os outros não. Os outros eram como se tivessem morrido pelo meio do caminho. (EVARISTO, 2016, p. 43).
}

A cena, projetada pela narração, pode levar o leitor a inúmeras inferências, como a do sentido da maternidade da personagem, de seu pertencimento. De certo modo, refere-se às múltiplas crenças da gênese que une indivíduos distintos, aqui, em específico, pelo cordão umbilical, como inevitável canal de ligação entre mãe e filho; fruto em desenvolvimento como propriedade da mãe e seu contínuo estado de pertença, concretizado pela bolsa que contém placenta e líquido amniótico. Seria esse, afinal, o milagre da vida?

As concepções acerca da maternidade são complexas, pois ela é um grande evento, uma peça-mãe rodeada de telespectadores ativos que se comportam como críticos por sempre terem uma opinião formada para "presentear" a genitora. É impossível, também, não pensar na romantização desse acontecimento, dos mitos e verdades, das dúvidas e incertezas que o cercam. Assim, o citado sentido de pertencimento também se refere à condição humana dessa mulher-personagem e de seus sentimentos. No caso do conto em destaque, para além dessa pertença, o conhecimento sobre sua condição social e de cor também auxiliam na projeção sobre a representação dessa personagem, instigando-nos à leitura.

É inegável que uma das características mais fantásticas da Literatura é sua capacidade de captar flashes da realidade e transpô-los para o universo ficcional, concretizando-os nas linhas de um texto literário pela atividade criadora do autor. Correlacionadas a esse aspecto, encontram-se diversas concepções da relação entre esses dois mundos, real e fictício, sendo a de mimeses, defendida por Aristóteles em 
sua Poética, uma das primeiras da história. Todavia, nos estudos sobre algumas correntes da literatura contemporânea e seus escritores, observa-se o surgimento de uma visão neorrealista que se afasta em partes do conceito mencionado, como aponta Schøllhammer (2009):

O que se encontramos, sim, nesses novos autores, é a vontade ou o projeto explícito de retratar a realidade atual da sociedade brasileira, frequentemente pelos pontos de vista marginais ou periféricos [...] Ora, discutindo um realismo que não se pretende mimético nem propriamente representativo, o problema ameaça tornar-se um paradoxo, uma vez que o compromisso representativo da literatura historicamente surge com a aparição do fenômeno realista [...] Diríamos, inicialmente, que o novo realismo se expressa pela vontade de relacionar a literatura e a arte com a realidade social e cultural da qual emerge, incorporando essa realidade esteticamente dentro da obra e situando a própria produção artística como força transformadora (2009, p. 5354).

Portanto, não é por acaso que a representação da vivência de Natalina, no conto "Quantos filhos Natalina teve?", de Evaristo (2016), assemelha-se à vida real de muitas mulheres brasileiras, principalmente das negras e periféricas, assim como a da personagem. Impulsionada pelos movimentos sociais, principalmente 0 feminista e Queer, bem como pelo fortalecimento dos Estudos Culturais, a representação de grupos marginalizados tem se destacado na produção literária brasileira contemporânea. Tal retrato constitui-se em uma das principais e mais importantes linhas de forças dessa produção, perfeitamente possível de ser relacionada à obra de Conceição Evaristo, que revela em seus escritos um mosaico composto por mulheres-avós, mulheres-mães, mulheres-filhas e mulheres-netas, dentre outras figurações.

É válido registrar, também, que, para além da diversidade de gêneros, formas e temas do cenário múltiplo da produção contemporânea, a prática desses autores e suas obras, que buscam pela representação dos sujeitos subalternizados, alteram fortemente as concepções relacionadas ao ensino de literatura na esfera escolar, uma vez que elas têm provocado um movimento de fratura em relação a certa visão conservadora e tradicional sobre o ensino do texto literário. Com efeito, no processo de ensino, aquele determinado cânone, hegemônico e falocêntrico, apesar de possuir um valor importante para a preservação e modo de compreensão da história dita "oficial", não deve ser o único regulador e medidor do que, porventura, possa se caracterizar como literatura de qualidade ou não. Afinal, por se tratar de um patrimônio cultural e levantar discussões referentes a todos aqueles que permaneceram do lado de fora desta classificação, bem como os motivos que levaram a isso, o cânone deve ser conhecido para ser contestado.

Os estudos de Rouxel (2013), por exemplo, apresentam importantes considerações sobre o que a estudiosa entende como avanços em torno do ensino da literatura, cujo resultados indicam uma nova configuração capaz de ampliar a reflexão sobre as práticas metodológicas voltadas à educação literária, aqui entendida como o processo que visa à formação de leitores competentes e hábeis 
para compreender e interpretar a complexidade dos múltiplos textos literários e reconhecer sua importância como força humanizadora do homem. Inicialmente, a pesquisadora evidencia as mudanças em três paradigmas que envolvem a concepção de literatura: a primeira ressalta que, de uma visão da literatura como objeto restrito, passou-se para uma visão mais expansiva do que ela seja; a segunda, corresponde a uma ampliação da compreensão dos múltiplos processos correlacionados aos textos, isto é, a literatura passa a ser estudada em sua complexidade de agentes; por fim, a terceira, e mais relevante para este trabalho, evidencia que o texto literário não possui apenas função estética, mas é, antes de tudo, um ato de comunicação, no qual "[...] há um interesse pelo conteúdo existencial das obras, pelos valores éticos e estéticos de que são portadoras" (ROUXEL, 2013, p. 18).

Quanto à leitura literária, a estudiosa também realiza importantes considerações: nega-se a adoção de um leitor ideal e foca-se em um leitor real, sujeito plural e empírico; o texto literário, que era visto como uma obra já terminada, agora é visto como um texto que requer a atualização do outro, nesse caso do estudante-leitor em formação. Nota-se que cabe ao professor auxiliar seus alunos por meio da mediação no processo de textualização da obra literária; o último aspecto, e o mais importante, reside no fato de que não se deve adotar uma visão totalmente distanciada em relação ao texto, valoriza-se, portanto, o estabelecimento da relação texto-leitor que se "[...] traduz por uma reabilitação no processo de identificação" (ROUXEL, 2013, p. 19).

Esse processo de identificação é relevante, uma vez que, após o fim da ditadura militar no Brasil, diversas perspectivas referentes à política nacional foram reconsideradas, sendo a reforma da Educação uma delas. A partir desse processo, a democratização do ensino no país se consolida com a promulgação da Constituição Federal em 5 de outubro de 1988, alterando, por exemplo, as configurações dos espaços escolares, uma vez que se reconhece a Educação como um direito de todos, sendo ela assegurada a qualquer indivíduo.

Com a Lei de Diretrizes e Bases da Educação (BRASIL, LDB 9394/96), reafirma-se a necessidade de integração e o reconhecimento da diversidade em suas múltiplas formas, aspectos essenciais para a discussão que aqui se apresenta. Ao se considerar, a exemplo, que na prática cotidiana o convívio com a diversidade não se dá de maneira pacífica, pois basta observar os crescentes números de casos de agressões físicas e/ou psicológicas, racismo, LGBTfobia, dentre outras formas de violência, mesmo que simbólicas, verifica-se que a existência do inciso IV do Art. $3^{\circ}$. da LDB (BRASIL, LDB 9394/96), de "respeito à liberdade e apreço à tolerância", não é garantia de erradicação dos problemas mencionados.

De qualquer modo, vale registrar o fato de que a Lei se caracterizou como respaldo e proteção para todos que defendem uma educação de reconhecimento e apreciação da diversidade e diferença. Decorrente desse sentido, é possível registrar alguns progressos conquistados como o do avanço no ensino da própria Língua 
Portuguesa, em específico da Literatura, que assumiu novas perspectivas, dentre elas a da necessidade e defesa da adoção de textos literários não apenas pertencentes ao cânone, formado por um perfil dominantemente masculino, heterossexual, branco, de classe média-alta, morador dos grandes centros, que, insuficientemente, comporta a representação dos diversos grupos de indivíduos (co)existentes no espaço escolar e na sociedade.

Os progressos acima indicados, no campo do ensino de Literatura, são, pois, fundamentais para a abertura de espaços de ensino e aprendizagem, tendo em vista que muitos estudantes não se reconhecem como parte e sujeito na produção artística compreendida como sendo de prestígio para a sociedade, dentre elas a Literatura, isso porque sua (r)exi(s)tência, quando presente, encontra-se de forma marginalizada, distorcida, até mesmo fragmentada, por uma perspectiva de um sujeito-escritor de uma realidade completamente distinta, tornando os textos muitas vezes povoados por personagens estereotipados, como demonstram estudos de Dalcastagnè (2012), dentre outros pesquisadores. Além disso, esses estudantes, muitas vezes, não se veem representados, também, naqueles que produzem Literatura ou naqueles que, porventura, discutem as obras literárias, tornando turva a visão sobre quem as leem.

Logo, por meio do aumento da representatividade de escritores e obras, os alunos-leitores podem passar a se sentirem como parte desse processo cultural ao verem suas realidades nas páginas de um texto literário e/ou na figura do escritor, condição essa que os empoderam e os tornam abertos a (re)conhecer outras leituras e formas de arte. Ressaltamos que não assinalamos a necessidade de ocorrer a delimitação de um único espécime de obras literárias ou temas para esses sujeitos subalternizados historicamente e que eles devem apenas consumir um único tipo de texto literário. Afinal, assim como Candido (2017), acreditamos na literatura como um direito universal do homem e resgatamos a experiência mencionada por ele em "Direito à Literatura", ao falar sobre o trabalho com a literatura proletária na Rússia, discorrendo que, na ocasião, os trabalhadores não se contentaram somente com a leitura da literatura populista que estava sendo ofertada a eles, mas reivindicaram o direito de também lerem Balzac, Stendhal e Flaubert, nomes marcantes da literatura canônica.

O que destacamos é a necessidade do trabalho com obras literárias e escritores que contemplem as diversas formas de existência em sala de aula, sobretudo de textos e autores marginalizados, renegados e esquecidos pela história literária e seu cânone, por motivos como identidade de gênero, classe social, sexualidade, raça e/ou etnia, grau de letramento, realidades abordadas, dentre outros aspectos, que não definem a qualidade estética-literária de um texto, mas que sua abjeção demonstra a intolerância e pré-conceito presente na sociedade. Como mencionado, o espaço escolar é ocupado por sujeitos múltiplos e plurais, que possuem o direito de desenvolver uma relação de identidade e pertencimento frente ao texto literário por meio das suas vivências representadas e, assim, também 
defender essa perspectiva como símbolo de resistência.

A propósito, Tinoco (2013) realiza uma denúncia a respeito de alguns problemas da escola contemporânea, na qual registra que eles nada mais são que desafios já conhecidos, embora com roupagens pós-modernas, oriundos de uma política neoliberal. Vale a pena realizar uma pausa para acrescer a essa discussão uma das maiores contradições brasileiras: a dos cidadãos que se autointitulam como "liberais na economia e conservadores nos costumes", bordão tragicômico que impulsionou e promoveu a campanha eleitoral de algumas figuras da política nacional. Frente a essa realidade, aparentemente trágica também na realidade escolar, o pesquisador ressalta a necessidade de posicionamento:

Não há mais como imaginar uma escola periférica, à margem dos acontecimentos diários colados neste jorro informacional disformemente globalizado que inunda nossos ouvidos e olhos, desejos e valores. Inundação informativa que avança em todos os níveis, já que até a universidade não pode mais se considerar tipo ideal de espaço construtivo em que a teoria e prática interagem sob uma óptica social integracionista. (TINOCO, 2013, p. 137).

Sob tal ótica, Tinoco admite que deve ocorrer um processo de adaptação da nova realidade pela escola, haja vista que ela não se encontra à margem dos acontecimentos contemporâneos e dos problemas da sociedade, caso contrário o ambiente escolar estaria sujeito à perda de sua identidade social e coletiva, bem como de sua função:

Ou essa nossa nova escola - professores, alunos, agentes administrativos -
se adapta produtivamente à realidade contemporânea ou estará fadada a
perder o rumo da história nacional, regional e mundial. Adaptação produtiva,
no sentido de renovar a crítica aos costumes, aos valores, aos preconceitos;
no sentido de redirecionar o olhar do aluno para a função cultural da leitura
como veículo de conscientização social e fonte de prazer estético - sentidos
de ética e estética, na escola, precisam reencontrar seus esforços
privilegiados, revelados por metodologias exigentes, além de só
repetitivamente originais [...]. (TINOCO, 2013, p. 137).

Portanto, cabe à escola desenvolver e aprimorar os olhares críticos dos seus estudantes, chamando a atenção para a realidade social dos sujeitos, principalmente daqueles que estão em maior situação de vulnerabilidade. Desconstruir, nesse sentido, os preconceitos que nos bloqueiam a reconhecer e aprender por meio da existência do Outro, em uma relação de alteridade. Logo, não se pode perder de vista a atenção aos costumes que circundam e moldam a prática de agir e pensar de nossos alunos, e que, na maioria das vezes, mecanizam e padronizam a vida de grande parte da sociedade devido às políticas neoliberais. Essa mecanização do olhar produz um olhar de que todos os sujeitos devem ser iguais.

Nesse contexto, Tinoco (2013) ressalta que a Literatura assume uma dupla identidade: a primeira, de que ela trata de um veículo de conscientização social; e a segunda, que ela é fonte de prazer estético. Com efeito, ao se adotar na sala de aula textos e obras de autores subalternizados na e pela história, a escola, instituição 
social consolidada, reafirma a existência desses indivíduos e legitima que a produção artística-cultural não está restrita a uma elite formada por indivíduos brancos, predominantemente homens. Justifica-se, portanto, a importância de se estender ao espaço escolar tais vozes, que podem ser encontradas, por exemplo, em Conceição Evaristo, especialmente em um dos seus textos: "Quantos filhos Natalina teve?".

\section{Um olhar sobre a obra...}

A escrita de textos literários de e sobre mulheres não se compõe, de forma alguma, como uma única história, pois elas expressam visões plurissignificativas de mulheres que se encontram sob perspectivas diferentes, isto é, em lugares de fala distintos. Além disso, a própria concepção do ser (e estar) mulher (na sociedade) é variável, como apontou Beauvoir (2016) ao dizer que "[...] em verdade, ninguém nasce gênio: torna-se gênio; e a condição feminina impossibilitou até agora esse 'tornar-se'" (p. 190), frase célebre caracterizada como um importante marco do feminismo contemporâneo.

Ao compreendermos os processos culturalmente institucionalizados determinantes na construção identitária, histórica e ideológica do que, porventura, caracteriza-se como "ser mulher", somos capazes de refletir (e quem sabe compreender) o papel e o espaço ocupado por elas em nossa sociedade. $O$ feminismo contemporâneo desenvolve-se não como tentativa de resposta a esse questionamento, mas para denunciar e combater a constituição/formação dos papéis sociais que oprimem e impõem às mulheres um determinado modo de expressar sua existência, que é subordinada ao homem cisgênero, heterossexual, heteronormativo. Portanto, observa-se o feminismo como meio de subversão da norma historicamente construída, que torna desigual a relação binária.

Embora seja possível observar, portanto, os avanços no campo de discussão sobre as pautas das mulheres, desde o surgimento da primeira onda da história do feminismo, também chamada de sufrágio feminino, até o começo da segunda metade do século XX, havia ainda um problema a ser resolvido no próprio movimento: o da visão uniforme sobre todas mulheres, pois era necessário explorar a diferença entre as vivências do feminino de mulheres brancas e negras, afinal, elas vêm de lugares diferentes e ocupam espaços distintos no corpo social. Frente a essa necessidade, observa-se o surgimento da terceira onda do feminismo, agora com a intenção de romper uma visão de:

[...] universalização da categoria mulher. Esse debate de se perceber as várias possibilidades de ser mulher, ou seja, do feminismo abdicar da estrutura ao se falar de mulheres e levar em conta as outras intersecções, como a raça, orientação sexual, identidade de gênero, foi atribuído mais fortemente à terceira onda do feminismo [...]. (RIBEIRO, 2019, p. 20).

Observa-se que na América Latina, em especial no Brasil, pela sua composição social etnicamente híbrida, pluricultural, desigual, racista e misógina, a perspectiva de globalização oriunda da segunda onda do feminismo não foi capaz de abarcar os 
diferentes lugares de fala e os espaços ocupados pelas mulheres. Carneiro (2003) observa a origem social do feminismo negro, por exemplo, a partir de um duplo problema: primeiramente, pelo enfrentamento do machismo recorrente no movimento negro até então ocupado e liderado majoritariamente por homens; e, por segundo, pela resposta ao racismo no movimento feminista manifestado no privilégio das pautas das mulheres brancas frente às das negras. Tal fratura provoca, como resultado, "[...] a consciência de que a identidade de gênero não se desdobra naturalmente em solidariedade racial intragênero" (CARNEIRO, 2003, p. 120, grifo da autora).

Sob esse enquadramento, pode-se verificar que a literatura de autoria feminina negra se caracteriza por um modo particular, dotado de uma vivência que demostra as interseccionalidades vividas por estas mulheres. Essa potencialidade oportunizada por essa categoria de texto literário é substancial para a formação dos alunos, haja vista que um dos principais meios para o combate às múltiplas formas do racismo e desigualdades é o de compreender o nosso lugar frente a estes aspectos, para reconhecer nossos privilégios sempre que possível e ter acesso à vivência do outro, ouvi-los e deixar que se expressem. Sendo assim, apesar de a literatura ser fruto da criatividade imaginativa dos seres humanos e não possuindo obrigação alguma com a realidade, é inegável que as experiências de cada escritora e seu local de pertencimento fazem de cada texto literário, escrito por mulheres negras, manifestações ímpares, dotadas de significância e de veracidade pulsantes. É sobre esse poder (da palavra e voz), de uma das autoras negras contemporâneas mais significativas da literatura brasileira, que exploraremos um de seus textos.

Conceição Evaristo é seu nome. Destaca-se o projeto literário extraordinário construído por ela, dotado de uma força impressionante que parece estar vivo, pulsante. Muitos dos seus textos literários carregam consigo certa carga de sensibilidade lírica, mesmo quando abordam em algum nível as mazelas da sociedade, principalmente aquelas relacionadas à sua vivência e de seu povo, como o racismo, machismo e a desigualdade social, por exemplo. Evaristo é instintivamente provocadora: sua trajetória é marcada por desafios, de todo o sistema, ao ocupar a cena literária, por contestar esse espaço para si, e também é desafiada por alguns sujeitos, ao insistirem em deslegitimar sua produção, que, como resposta, tem alcançado cada vez mais reconhecimento pela crítica e outros meios de legitimação. Vale destacar a origem humilde dessa escritora negro-brasileira, que nasceu em uma favela de Belo Horizonte, completamente fora do eixo Rio-São Paulo de produção cultural, e após os 25 anos de idade mudou-se para o Rio de Janeiro onde passou a cursar Letras na Universidade Federal do Rio de Janeiro (UFRJ), sendo logo aprovada em um concurso para magistério. Desde a década de oitenta do século passado, Conceição atua em movimentos sociais da população negra, estreando em 1990 na produção literária na série chamada Cadernos Negros. É Mestra em Literatura Brasileira, pela Pontifícia Universidade Católica do Rio de Janeiro (PUC-RJ), e Doutora em Literatura Comparada, pela Universidade Federal 
Fluminense. Nota-se que, desde muito cedo, Evaristo esteve ligada aos movimentos sociais e representa uma voz importante para o movimento negro e feminista.

Por conhecer a dura realidade social das populações subalternizadas, sua obra é composta por contos, poemas e romances, que versam sobre temas do cotidiano dessas camadas desprivilegiadas no âmbito político, social e econômico, bem como exaltam a força da população negra, especialmente a das mulheres. É o que ocorre em Olhos D’água (2016), composta por quinze contos, que, de modo geral, tematizam as inúmeras violências e desigualdades sociais que assolam o país. Torna-se importante destacar o impressionante projeto gráfico deste livro, desde sua capa, com a imagem de olho texturizado com uma aquarela azul brotando dele para representar as águas que jorram dos olhos (lágrimas), sua localização ocupa todo o centro, até a cor azulada da fonte utilizada na impressão. Tudo no livro se remete aos olhos marejados, ou seja, à água - todos esses elementos paratextuais necessitam serem explorados pelos alunos para que eles compreendam que todo o trabalho gráfico é intencional.

A obra é uma espécie de rio de águas salgadas e a cada conto é um curso desse rio-vida de lágrimas, pois, assim como as partes conhecidas de um rio dadas pela Geografia, o livro contempla os mesmos caminhos. A nascente, local no qual se dá a origem de um curso de água, é o próprio ato da escrita de Conceição, sua força criativa de compor, pois é dela que tudo aflora e brota. O leito, espaço ocupado pelas águas e o seu caminho é a própria vida, é de onde emergem os personagens. A margem, o ponto de contato da água com a terra na beira do rio, pode representar a posição que nós leitores estamos em relação à obra (aqui, pode haver uma variação, pois muitos se jogam na água não contentes em ficarem à margem). Os afluentes são os cursos d'água que alimentam o rio principal ao desaguar nele, como as histórias de todos os personagens que compõem a obra. Os meandros, isto é, o caminho tortuoso de um curso, representam os caminhos dos personagens presentes no livro, pois a vida deles segue uma forma sinuosa também. A confluência, ponto de conjunção entre dois fluxos de água, representa a interseccionalidade das vivências das personagens (e de muitos leitores), as violências e as desigualdades. Por fim, mas não menos relevante, a foz, o ponto de desague do rio, representa a continuidade da obra, o oposto de seu fim, é o local onde o universo ficcional não fica contido na última página do livro, mas segue seu fluxo e se transforma.

A água no imaginário comum e coletivo representa a vida, a fertilidade, por ser agente primordial na fecundidade, simboliza a transformação (pelas suas três fases) e a purificação (do corpo e da alma). É o elemento da cura, espiritualidade, dos sentimentos e das emoções. Representa a regeneração para muitos, a sabedoria e memória, elementos já cantados por Elza Soares e Pitty (2017) na canção "Na pele":

$[\ldots]$

A vida tem sido água

Fazendo caminhos esguios 
Se abrindo em veios e vales

$\mathrm{Na}$ pele leito de rio

Contemple o desenho fundo

Dessas minhas jovens rugas

Conquistadas a duras penas

Entre aventuras e fugas

Observe a face turva

O olhar tentado e atento

Se essas são marcas externas

Imagine as de dentro

[...] (SOARES; PITTY, 2017)

Na letra há ligação entre a vida e a água, os caminhos dos veios e vales deixados pelo curso de um rio metaforizando as rugas-marcas de Elza Soares e, se essas marcas são as visíveis, como os caminhos do rio, as internas são mais profundas ainda. Vale ressaltar que a maior concentração de água doce está nos lençóis freáticos, espaços subterrâneos, assim como as marcas-memórias de Soares. A mesma força da água está presente na obra de Evaristo, pois essa abundância líquida (e lírica) da prosa ou poesia da autora demonstra a força de um eu-líquido presente e consciente.

É evidente que Olhos D’água, de Conceição Evaristo (2016), é uma obra dotada de grande potencialidade para o trabalho no espaço escolar. Trata-se de um texto complexo, não pela dificuldade linguística, que, por vezes, dificulta a leitura literária na educação básica, mas por oportunizar fértil e prolífero texto simbólico de composição única. Exposto isso, selecionamos um dos cursos de água presentes para análise (um conto) a seguir, a fim de explorar algumas possibilidades para o trabalho em sala de aula com foco na educação literária. Importa dizer que um texto literário de qualidade nunca se esgota, sendo possível retomá-lo sempre e (re)descobri-lo.

\section{Um mergulho nessas águas...}

O conto "Quantos filhos Natalina teve?" é um dos mais expressivos da coletânea. Destaca-se a sua capacidade de oportunizar a abordagem de algumas problemáticas que, apesar de comporem o berço da história da civilização e da nossa sociedade desde sua formação, ainda nos afetam e sempre estão presentes nas discussões contemporâneas, principalmente as que envolvem os obstáculos em ser e estar mulher na sociedade brasileira, tais como a exploração psicológica e do corpo e a violência. O texto também se volta para a capacidade de resiliência dos indivíduos, pois, apesar das adversidades do cotidiano da personagem ela não perde a fé de recomeçar sua vida ao lado do seu único filho.

Partindo de uma análise da forma, observa-se que o conto é narrado em terceira pessoa, isso é, por um narrador heterodiegético. Doze contos de Olhos D’água (2016) estão narrados em terceira pessoa, sendo outros dois em primeira e um que utiliza tanto a primeira quanto a terceira pessoa. A escolha dessa espécie de 
narrador demonstra a intenção de colocar a voz-sujeito em uma posição mais ampla frente ao texto, para que ele seja capaz de narrar a totalidade dos fatos sem a presença do "eu". A focalização se dá pela onisciência seletiva, na qual o narrador registra as impressões de sentimento da personagem protagonista. Nota-se, também, que há presença do discurso indireto livre em alguns trechos. Quanto ao tempo, ele se dá pela referência psicológica, não estabelecendo uma ordem cronológica, aspecto visível no primeiro parágrafo do conto, conforme o trecho transcrito na introdução deste trabalho. Já em relação ao espaço, observa-se o ambiente urbano, permeado por uma atmosfera de grande violência, aspecto recorrente na narrativa contemporânea, como apontado por Resende (2008), ao dizer que "[...] talvez o tema mais evidente na cultura produzida no Brasil contemporâneo: a violência nas grandes cidades" (p. 32, grifo da autora).

A narrativa apresenta a história de Natalina e sua relação com a maternidade. Torna-se interessante observar o próprio nome da personagem: a etimologia da palavra natal está ligada ao sentido de nascer e nascimento, quanto ao sufixo "ina" está relacionado à área de química e biologia por referir-se às substâncias cujo significado é "da natureza de/algo, feito de, derivado de, proveniente de". No caso do conto, observamos um sentido duplo: o primeiro está relacionado ao fato de que a personagem carrega em seu ventre diversas vezes um feto, logo é da natureza de Natalina gestar, não importando se a gravidez ocorre de forma acidental, planejada (ou melhor, explorada) ou oriunda de uma violência; o segundo sentido está relacionado a seu "primeiro filho", embora sendo o da última gravidez, visto que a gestação dele é o (re)nascimento de Natalina para a vida, a sua chegada a vida adulta.

O conto possibilita o confronto com diferentes formas de exploração e de violência pelas quais Natalina enfrenta no decorrer de sua existência. Começando com a psicológica, pois, ao engravidar pela primeira vez, sua mãe diz que a levará para Sá Prexedes caso os chás abortivos não funcionem. Nesse momento, a personagem protagonista revive o medo que a acompanha desde sua infância, pois sua mãe incutira nela o pavor em relação à Sá Praxedes, uma parteira responsável também por abortos clandestinos:

[...] la tentar mais um pouco de beberagens, se não desse certo, levaria a menina a Sá Praxedes. A velha parteira cobraria um pouco, mas ficariam livres de tudo. Natalina segurou o temor em silêncio. Sá Praxedes, não! Ela morria de medo da velha. Diziam que ela comia meninos. Mulheres barrigudas entravam no barraco de Sá Praxedes, algumas, quando saíam, traziam nos braços as suas crianças, outras vinham de barriga, de braços $\mathrm{e}$ mãos vazias. Onde Sá Praxedes metia as crianças que ficavam lá dentro? Sá Praxedes, não! A mãe de Natalina e as outras mães sabiam que era só dizer para as crianças que iam chamar a velha e os filhos ficavam quietos, obedeciam. (EVARISTO, 2016, p. 44-45).

Evidencia-se, ainda, a partir da citação, um olhar de inocência da criançaNatalina, pois ela e as outras crianças daquela comunidade têm uma visão fantasiosa 
do que de fato ocorria com os bebês, que não "saíam" nos braços das mães e, mesmo após uma certa idade, esse horror ainda a acompanha, sendo maior que o próprio desejo de se ver livre do feto que carrega em sua barriga. É evidente que o medo nela incutido pela mãe ganha contornos de exploração psicológica, haja vista que ela, ainda mais velha, revela um trauma em relação à velha parteira relacionado à ideia da maternidade. A critério de inferência, uma das possibilidades de leitura do nome Praxedes está na relação com a palavra "práxis", relacionado ao sentido de ação e conduta, contrárias à teoria, ao contrapor ao conto observamos que Sá Praxedes é a execução precisa para resolver o problema da gravidez indesejada das mulheres da comunidade, nesse sentido, contra os chás abortivos, que, teoricamente, deveriam funcionar, mas sem garantias de êxito em todos os casos. Durante as aulas, é necessário que os professores instiguem seus alunos a refletirem sobre as possibilidades de interpretação que o texto literário oferece, isto é, as possíveis leituras, para que as aulas não fiquem apenas na superficialidade do texto literário.

Dando sequência, a inocência de Natalina se rompe quando ela descobre os prazeres da carne e engravida. É importante ressaltar que no texto não está demarcada a idade com que a personagem engravidou, mas o narrador enuncia que ela era quase uma menina quando pariu seu primeiro filho: "Bilico, amigo de infância, crescera com ela. Os dois haviam descoberto juntos o corpo. Foi com ele que ela descobriu que, apesar de doer um pouco, o seu buraco se abria e ali dentro cabia o prazer, cabia a alegria" (EVARISTO, 2016, p. 45). O apelido Bilico também carrega consigo uma certa dose de infantilidade, que se contrapõe ao ato sexual.

A partir de então, a personagem engravida três outras vezes, sendo que apenas na última gravidez ela a deseja, recusando nas outras vezes o bebê, como pode ser observado no trecho em que o narrador expõe que "[...] a segunda gravidez foi também sem querer, mas ela já estava esperta. Brincava gostoso com os homens, mas não descuidava" (EVARISTO, 2016, p. 46). Ressaltamos a utilização do verbo brincar para se referir à prática sexual, sendo assim, observa-se que o narrador distancia Natalina de uma mulher já "feita", ou seja, ela ainda não havia se "feito" adulta. Nesse sentido, a personagem não se vê como mãe nas vezes em que ela engravidou, não via o feto como seu filho, com exceção da última gravidez. O trecho abaixo ajuda a compor o que foi expresso ao evidenciar a relação de Natalia com as suas três primeiras gravidezes:

Os outros eram como se tivessem morrido pelo meio do caminho. As outras barrigas ela odiara. Não aguentava se ver estufando, estufando, pesada, inchada e aquele troço, aquela coisa mexendo dentro dela. Ficava com o coração cheio de ódio. Enjoava e vomitava muito durante quase toda a gravidez. Na terceira, vomitou até na hora do parto. Foi a pior gravidez para Natalina. (EVARISTO, 2016, p. 43).

No trecho, observa-se a repetição do verbo estufar duas vezes pelo narrador para fazer o leitor visualizar o curso da gravidez, a utilização do verbo demonstra 
como se a barriga de Natalina fosse um balão prestes a explodir. Destacam-se, também, outros adjetivos utilizados (pesada e inchada), o uso do pronome demonstrativo "aquele", para marcar a posição especial do feto em relação à pessoa do discurso, situando-o no espaço, no tempo e no próprio discurso do narrador, como também da personagem (o de afastamento).

Ademais, durante os processos de experiência da gestação, a personagem sofre a exploração de seu próprio corpo, que se dá em duas grandes frentes: a primeira delas, como objeto, ocorre na casa de um casal de classe econômica alta, na qual trabalha como doméstica, pois, uma vez que a esposa do patrão não consegue gerar um filho, Natalina recebe a proposta de gerá-lo:

\begin{abstract}
A terceira gravidez, ela também não queria. Quem quis foi o casal para quem Natalina trabalhava. Os dois viviam bem. Viajavam de tempos em tempos e quando regressavam davam sempre festas. [...] Um dia, enquanto divagava em seus sonhos de pretensa dona, o telefone tocou. Era a patroa que ligava do estrangeiro, em prantos, e lhe pedia ajuda. Ela queria e precisava ter um filho. [...] A mulher queria um filho e não conseguia. Estava desesperada e envergonhada por isso. Ela e o marido já haviam conversado. Era só a empregada fazer um filho para o patrão. Elas se pareciam um pouco. Natalina só tinha um tom de pele mais negro. (EVARISTO, 2016, p. 47).
\end{abstract}

Esse trecho suscita alguns pontos interessantes para observação: o primeiro, que resgata temas sociais como o de útero de aluguel, mesmo que o narrador deixe claro que ela não recebeu por isso ao dizer algumas linhas abaixo: "Tudo certo. Deitaria com o patrão, sem paga alguma, tantas vezes fosse preciso" (EVARISTO, 2016, p. 47). Todo esse olhar para Natalina como apenas um meio para procriação se assemelha com a situação das Aias em O conto de Aia, de Margaret Atwood ${ }^{1}$, publicado pela primeira vez em 1985 - compreendemos que estabelecer relações entre textos é essencial para a ampliação do texto literário, portanto, essa abordagem pode (e deve) ser aproveitada em sala de aula. Apesar de ter aceitado conceber o filho do casal, observa-se que Natalina era vista somente como um objeto para uso dos patrões abastados, revelando um processo que expressa as relações de poder existentes entre sujeitos pertencentes a estratos sociais, políticos e econômicos diferentes; o segundo ponto se refere ao momento em que o narrador menciona o tom de pele da personagem, numa clara alusão à pele negra. Seria Natalina negra?

A segunda frente de exploração do corpo da personagem ocorre quando ela sofre uma violência sexual e mata o estuprador, porém dele engravidando:

O homem desceu do carro puxou-a violentamente e jogou-a no chão; depois desamarrou suas mãos e ordenou que the fizesse carinho. Natalina, entre ódio e o pavor, obedecia a tudo. Na hora, quase na hora do gozo, o homem

\footnotetext{
${ }^{1}$ A obra O conto da Aia, de Margaret Atwood (2017) é um romance distópico ambientado em uma região chamada Gilead - antigo Estados Unidos - onde a teonomia cristã é o regime totalitário em vigor. Nessa sociedade, as mulheres são as principais vítimas, perdendo todos seus direitos conquistados e liberdade, tornando-se propriedade dos seus maridos e sendo divididas de acordo com sua função na sociedade. Devido à infertilidade da maior parte das mulheres, aquelas que são férteis, chamadas de aias, passam a serem exploradas pelo sistema (e estupradas pelos comandantes - políticos) para gerarem filhos.
} 


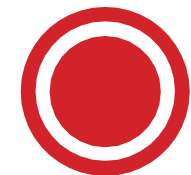

arrancou a venda dos olhos dela. Ela tremia, seu corpo, sua cabeça estava como se fosse arrebentar de dor. [...] Ele gozou feito cavalo enfurecido em cima dela. [...] Poucos meses depois, Natalina se descobrira grávida. (EVARISTO, 2016, p. 50).

O curioso é que, apesar de ter engravidado a partir de um estupro, essa é a única gravidez em que ela desejará conceber o filho. Pode-se ler tal sentimento como forma de avanço em relação ao contexto de violência no qual ela convive desde a infância, demonstrada não apenas pelo espaço, mas também pela sua relação com a mãe em uma violência psicológica pautada pelo medo. Portanto, é como se Natalina estivesse fadada a (con)viver com tal violência. Ao mesmo tempo, essa "aceitabilidade" da gravidez proveniente do estupro soa incompreensível para muitos leitores, mas é nesse momento que Natalina finalmente se forma como mulher-feita, como se as outras violências sofridas não fossem suficientes para que ela enxergasse sua condição na sociedade. Ou essa violência se dá para que a sociedade alienada possa visualizar a violência sofrida por ela? Porque somente quando fere o físico, quando se trata de um crime hediondo, quando causa repulsa na sociedade, é que ocorre alguma forma de compadecimento. Ironicamente, apesar da abominação, estupros ocorrem constantemente no cotidiano da sociedade brasileira. $^{2}$

Além disso, é na quarta gestação que a personagem se sente no poder de escolha, com domínio de seu próprio corpo, cujo filho seria somente dela, afirmação que pode se confirmar no seguinte trecho: "Estava feliz. O filho estava para arrebentar no mundo a qualquer hora. Estava ansiosa para olhar aquele filho e não ver a marca de ninguém, talvez nem dela" (EVARISTO, 2016, p. 50). Todavia, não se trata apenas de um direito de escolha involuntária, é como se esse filho fosse uma resposta a toda violência sofrida pela personagem. Nesse momento, Natalina é aquela que toma para si o controle e exerce também uma violência ao matar o estuprador:

Não, dessa vez ela não devia nada a ninguém. Se aquela barriga tinha um preço, ela também tinha tido o seu, e tudo tinha sido feito com uma moeda bem valiosa. Agora teria um filho que seria só seu, sem ameaça de pai, de mãe, de Sá Praxedes, de companheiro algum ou de patrões. E haveria de ensinar para ele que a vida é viver e é morrer. É gerar e é matar (EVARISTO, 2016, p. 49).

Apesar de ser uma breve análise, reconhece-se a grandiosidade do conto, que tematiza uma perspectiva do pertencimento da mulher negra na sociedade, bem como a visão desromantizada da maternidade, uma importante discussão contemporânea, posto que a personagem rompe com a visão tradicional e

2 Segundo o $13^{a}$ Anuário Brasileiro de Segurança Pública de 2019, nos anos de 2017 e 2018, houve o total de 127.585 ocorrências de estupro e estupro de vulneráveis - vale ressaltar que, segundo o mesmo documento, apenas $7,5 \%$ das vítimas notificam a polícia, ou seja, esse número é ainda maior. Outro dado alarmante é que $81,8 \%$ das vítimas eram do sexo feminino, desse total, $50,9 \%$ de mulheres negras. 
conservadora de maternidade compulsória criada pelo patriarcado. Compreende-se por maternidade compulsória o processo social, criado sobretudo por homens e legitimados pelos discursos religiosos e conservadores, a partir dos quais as mulheres são vistas principalmente como procriadoras, cuja função social é gerar uma outra vida.

Nessa perspectiva, tem-se em mente que as mulheres nascem com um instinto nato para a maternidade e que devem amar o processo de gestação e criação de seus respectivos filhos, porém a própria relação entre Natalina e sua mãe evidencia que tal concepção é errônea, haja vista que a educação pelo medo é ineficaz. Contudo, não se pode culpar somente a mãe de Natalina, uma vez que também ela cresceu em uma sociedade que a moldou dessa forma, isto é, ela é fruto de um processo de construção social injusto, desigual e marcado pela violência. Opostamente, no conto analisado, pode-se dizer que a personagem rompe tal perspectiva ao odiar a experiência de suas três primeiras gestações, bem como revelar a inexistência de um amor maternal por tais bebês, doando-os e os abortando sempre que possível.

Assim entendida, a experiência de natalina é um dos fragmentos das muitas escrevivências da escritora afro-brasileira, nas quais as personagens, segundo Conceição, nascem da vivência de seu cotidiano e de seu povo. Entretanto, para além da abordagem temática, o conto oferece recursos linguísticos importantes para a sua composição, sendo as escolhas lexicais substanciais para compreendermos a intenção do discurso do narrador. Esse é um dos aspectos mais importantes na educação literária, ou seja, a possibilidade de formar leitores capazes de estabelecer a relação entre a forma e conteúdo, ultrapassando a leitura para compreensão do enredo.

\section{O que pode essa escrita?}

Para o processo de educação literária não basta que o professor proporcione apenas a leitura de textos literários, a priori deve haver um processo significativo na própria escolha do objeto literário que será lido, que envolva desde o trabalho metodológico que será adotado até o objetivo esperado, que pode ser, por exemplo, o de, a partir do conto analisado, propiciar ao sujeito leitor o desenvolvimento crítico e consciente de seu lugar na sociedade face à mulher e a análise das escolhas no processo da construção do próprio texto literário.

O conto "Quantos filhos Natalina teve?" é um texto significativo para propiciar tal processo, haja vista que ele oferece uma experiência literária sobre certa realidade social que atinge boa parte da sociedade. É importante destacar que o conto apresenta uma de muitas outras vivências da mulher negra no país. Entretanto, a intenção da escritora não é a de limitar essas mulheres a esse lugar social, como se seu único papel fosse aquele ligado à violência, à exploração ou a outro tipo de marginalidade. Não por acaso, a autora dá ênfase ao poder de se valer da arte das palavras como um mecanismo de denúncia dessa realidade por meio da 
escrevivência.

Além disso, a partir da Lei 10.639/2003 (BRASIL, 2003) alterada pela Lei 11.645/2008 (BRASIL, 2008), torna-se obrigatório o ensino da história e cultura afrobrasileira e africana nas instituições de ensino, no âmbito público e privado. Logo, a inserção de autores e autoras negras é extremamente necessária, pois o apagamento e invisibilização da produção negra é uma das consequências do racismo no Brasil, portanto, os professores necessitam levar esses textos para a sala de aula e promover o debate sobre as pautas e temas levantados pela comunidade negra.

Ademais, pautando-se na multiplicidade do espaço escolar e reconhecendo a função da escola e a plurissignificação do texto literário, o conto analisado possibilita educar os alunos para a diversidade, tornando-os mais abertos à multiculturalidade e às diferenças, a ouvir outras vozes existentes. Ao mesmo tempo, o texto de Conceição Evaristo provoca o leitor sobre a tradição e algumas concepções enraizadas na sociedade quanto ao corpo da mulher, que ainda é visto como um objeto material, e a maternidade compulsória, discussões essas que podem levar os alunos a refletirem sobre certos discursos machistas e misóginos, ainda presentes nas práticas sociais contemporâneas.

Portanto, o conto mostra-se adequado para as expectativas do leitor pretendido, especificamente o do Ensino Médio. Pela mediação do professor, os alunos serão capazes de entrar em uma relação de alteridade e, em muitos casos, até estabelecer uma relação de identidade e pertencimento frente ao conto, à autoria negra e/ou uma das linhas de força da literatura contemporânea, que é justamente o da presença das vozes subalternizadas. Por fim, o conto mobiliza o leitor, instigando-o a estabelecer relações com outros textos na leitura, seja com outras obras literárias, adaptações cinematográficas e demais textos de outros gêneros, expandindo as referências estéticas, culturais e éticas, e contribuindo para que ele reflita sobre a realidade, sobre si mesmo e sobre o outro.

\section{Referências}

ATWOOD, Margaret. O conto da Aia. Rio de Janeiro: Rocco, 2017.

BEAUVOIR, Simone de. O segundo sexo: fatos e mitos. 3. ed. Rio de Janeiro: Nova Fronteira, 2016

BRASIL. Decreto-lei n. 9.394, de 20 de dezembro de 1996. Disponível em: <http://www.planalto.gov.br/ccivil_03/leis/l9394.htm>. Acesso em: 03 ago. 2020. BRASIL. Decreto-lei n. 10.639, de 9 de janeiro de 2003. Disponível em: http://www.planalto.gov.br/ccivil_03/leis/2003//10.639.htm. Acesso em 08 jul. 2020. BRASIL. Decreto-lei n. 11.645, de 10 de março 2008. Disponível em: http://www.planalto.gov.br/ccivil_03/_Ato2007-2010/2008/Lei/L11645.htm. Acesso em 08 jul. 2020.

CANDIDO, Antonio. Direito à literatura. In: Vários escritos. 6. ed. Rio de Janeiro: 
Ouro sobre azul, 2017.

CARNEIRO, Sueli. Mulheres em movimento. Estudos Avançados, São Paulo, v. 17, n. 49, p. 117-133, dez. 2003.

DALCASTAGNĖ, R. Um território contestado: literatura brasileira contemporânea e as novas vozes sociais. Iberic@l Revue d'études ibériques et ibéro-

américaines, n. 2, p.13-18, 2012. Disponível em: http://iberical.parissorbonne.fr/wp-content/uploads/2012/03/002-02.pdf Acesso em 20 jan. 2019. EVARISTO, Conceição. Quantos filhos Natalina teve? In: Olhos D'água. Rio de Janeiro: Pallas: Fundação Biblioteca Nacional, 2016.

FÓRUM BRASILEIRO DE SEGURANÇA PÚBLICA - FBSP. Anuário brasileiro de segurança pública [2019]. São Paulo, 2019. Disponível em:

<http://www.forumseguranca.org.br/wp-content/uploads/2019/09/Anuario-2019FINAL-v3.pdf>. Acesso em: 08 jul. 2020.

RESENDE, Beatriz. Contemporâneos: expressões da literatura no século XXI. Rio de Janeiro: Casa da Palavra; Biblioteca Nacional, 2018.

RIBEIRO, Djamila. Lugar de fala. São Paulo: Sueli Carneiro; Pólen, 2019.

ROUXEL, Annie. Aspectos metodológicos do ensino da literatura. Trad. Neide Luzia de Rezende. In: DALVI; Maria Amélia; REZENDE, Neide Luzia de; JOVERFALEIROS, Rita (orgs.). Leitura de literatura na escola. São Paulo: Parábola, 2013. p. 17-33.

SCHØLLHAMMER, Karl Erik. Ficção brasileira contemporânea. Rio de Janeiro: Civilização Brasileira, 2009.

SOARES, Elza; PITTY. Na pele [2017]. Disponível em:

<https://open.spotify.com/track/42pAh2iqNtnOw74hnlw3mZ>. Acesso em: 08 jul. 2020.

TINOCO, Robson Coelho. Percepção do mundo na sala de aula: leitura e literatura. In: DALVI; Maria Amélia; REZENDE, Neide Luzia de; JOVER-FALEIROS, Rita (orgs.). Leitura de literatura na escola. São Paulo: Parábola, 2013. p. 135-151. 